Environmental Microbiology

February 2008, Volume 10, Issue 2, Pages 433-445

http://dx.doi.org/10.1111/j.1462-2920.2007.01465.x

(C) 2008 Blackwell Publishing, Inc.
Archimer, archive institutionnelle de l'Ifremer http://www.ifremer.fr/docelec/

The definitive version is available at www.blackwell-synergy.com

\title{
Unexpected co-occurrence of six bacterial symbionts in the gills of the cold seep mussel Idas sp. (Bivalvia: Mytilidae)
}

\author{
Sébastien Duperron ${ }^{1,2,{ }^{*}}$, Sébastien Halary ${ }^{1,3}$, Julien Lorion ${ }^{1}$, Myriam Sibuet $^{2}$, Françoise Gaill ${ }^{1}$ \\ ${ }^{1}$ UMR 7138, Systématique, Adaptation, Evolution, Université Pierre et Marie Curie, 7 quai St Bernard, 75005 \\ Paris, France \\ ${ }^{2}$ Ifremer, Département Etude des Ecosystèmes Profonds, Centre de Brest, BP 70, 29263 Plouzané, France \\ ${ }^{3}$ Laboratoire d'imagerie intégrative, Institut Curie, Centre Universitaire d'Orsay, 91405 Orsay, France \\ *: Corresponding author : Duperron S., email address : sduperro@snv.jussieu.fr; Tel. 003314427 3995; Fax \\ 0033144275801.
}

\begin{abstract}
:
Bathymodioline mussels occur in chemosynthesis-based ecosystems such as cold seeps, hydrothermal vents and organic debris worldwide. Their key adaptation to these environments is their association with bacterial endosymbionts which ensure a chemosynthetic primary production based on the oxidation of reduced compounds such as methane and sulfide. We herein report a multiple symbiosis involving six distinct bacterial 16S rRNA phylotypes, including two belonging to groups not yet reported as symbionts in mytilids, in a small Idas mussel found on carbonate crusts in a cold seep area located north to the Nile deep-sea fan (Eastern Mediterranean). Symbionts co-occur within hosts bacteriocytes based on fluorescence in situ hybridizations, and sequencing of functional genes suggests they have the potential to perform autotrophy, and sulfide and methane oxidation. Previous studies indicated the presence of only one or two symbiont 16S rRNA phylotypes in bathymodioline mussels. Together with the recent discovery of four bacterial symbionts in the large seep species Bathymodiolus heckerae, this study shows that symbiont diversity has probably been underestimated, and questions whether the common ancestor of bathymodioline mussels was associated with multiple bacteria.
\end{abstract}

Keywords: symbiosis, mytilidae, Idas, Bathymodiolus, cold seeps, eastern Mediterranean 


\section{Introduction}

The genus Idas (Bivalvia: Mytilidae) encompasses small mussels found on sunken woods and whale bones in the Pacific ocean and Adriatic sea (Deming et al., 1997; Distel et al., 2000; Bolotin et al., 2005; Pailleret et al., 2007), as well as cold seeps in the Gulf of Mexico and Eastern Mediterranean (Gustafson et al., 1998; Olu-LeRoy et al., 2004). These are close relatives to the large mussels, mainly of the genus Bathymodiolus, which occur, worldwide but exclusively, at cold seep and hydrothermal vent sites (Distel et al., 2000; Iwasaki et al., 2006; Jones et al., 2006). The major characteristic feature of Bathymodiolus is their successful association with endosymbionts, mainly methanotrophic and sulphideoxidizing Gammaproteobacteria, which occur within specialised bacteriocytes located in the gill epithelium of the mussel and ensure a chemosynthetic primary production benefiting to their host (Fisher, 1990; DeChaine and Cavanaugh, 2005). For this reason, Bathymodiolus have been the subject of intensive studies investigating structural, functional and ecological aspects of their symbiotic associations in the last two decades (Fisher, 1990; Von Cosel, 2002; DeChaine and Cavanaugh, 2005; Stewart et al., 2005). Evolutionary aspects of symbiosis have been less studied. Host phylogeny supports the hypothesis that whale falls and sunken woods have served as evolutionary stepping stones for the colonisation of deep-sea cold seeps and vents by chemosynthesis-fuelled mytilids, and that small Idas-like mussels are the actual representatives of intermediate stages (Distel et al., 2000). Recent molecular studies on Bathymodiolus indicate that bacterial symbionts might be more diverse than previously thought both at the strain and 16S rRNA levels, and that symbionts might be environmentally transmitted, questioning the biogeography and evolution of symbiotic bacteria (Won et al., 2003; DeChaine et al., 2006; Duperron et al., 2007b). Data regarding symbiosis in small Idaslike mussels should thus improve our understanding of the evolutionary steps leading to the 
symbioses we observe today in mytilids; to test to which extent mussels were pre-adapted to colonise seeps and vents, and whether methane- or sulphide-oxidizing symbionts appeared first. Up to now, the only report indicates the presence of sulphide-oxidizing symbionts in the gill of I. washingtonia from a whale fall in the Santa Catalina Basin, but is based only on TEM observation and enzyme assays (Deming et al., 1997).

In this study, we provide the first molecular investigation of symbiosis in a small mussel, up to $1.5 \mathrm{~cm}$ in length, tentatively assigned to the genus Idas based on shell size and morphology. Mussels were attached by byssal threads to authigenic carbonate crusts associated with fluid seepages, which were collected north of the Nile Delta at a depth of $2130 \mathrm{~m}$ during the Nautinil cruise (eastern Mediterranean; chief scientist J.P. Foucher). Mussels likely sit at the interface between methane-enriched fluids and bottom seawater, and are part of a macrofaunal community which also includes vestimentiferan tubeworms and galatheid crabs. Comparative sequence analyses were performed to confirm the affiliation of mussels to the genus Idas and to asses the diversity of symbiotic bacteria using cyotochrome oxidase subunit I (COI) and bacterial 16S rRNA genes, respectively. The potential of symbionts to perform sulphide oxidation, autotrophy and methanotrophy was tested by amplifying fragments of adenosine 5'-phosphosulfate (APS) reductase, ribulose 1,5bisphosphate carboxylase/oxygenase (RubisCO) and particulate methane monooxygenase (pmoA) genes respectively. Fluorescence in situ hybridizations (FISH) were used to confirm the status of bacteria as symbionts, and stable isotope analysis to confirm their nutritional role. 


\section{Materials and methods}

\section{Samples}

Six specimens of Idas sp., up to $1.5 \mathrm{~cm}$ in length, were collected with the manned submersible Nautile during the Nautinil cruise to the eastern Mediterranean (2003, chief scientist: J. P. Foucher). Specimens occured in irregularities at the surface of two authigenic carbonate crusts which were collected from a pockmark area located in the 'Central Province', north of the Nile deep sea fan, during Dive $14\left(32^{\circ} 38.4 \mathrm{~N}, 29^{\circ} 55.0 \mathrm{E}, 2129 \mathrm{~m}\right.$ depth). The collection area corresponds to the lower slope of the Centre Nile Province described in Bayon et al (Bayon et al., submitted). Upon recovery, mussels were dissected, one gill and a fragment of the foot were frozen for DNA and stable isotope analysis, and the second gill and a part of the foot were fixed for FISH (see below). Shells were saved to allow for the exact determination of the species by taxonomists.

\section{Gene amplification, cloning and sequencing}

DNA was extracted individually from gill tissue of four specimens using a FastDNA $®$ SPIN KitPrep (Qbiogene, CA) with bead beater disruption of the cells. The gene encoding bacterial 16S rRNA was amplified from each specimen as described elsewhere (Duperron et al., 2005). Cytochrome oxidase subunit I (COI) mitochondrial gene was amplified with the forward primer LCO 1490 (Folmer et al., 1994) and the specific reverse primer H691 (5'GTRTTAAARTGRCGATCAAAAAT-3') using the following PCR cycling conditions: initial denaturation at $94^{\circ} \mathrm{C}$ for $3 \mathrm{~min}$ followed by 35 cycles at $94^{\circ} \mathrm{C}$ for $1 \mathrm{~min}, 50^{\circ} \mathrm{C}$ for $1 \mathrm{~min}\left(45^{\circ} \mathrm{C}\right.$ for the first 5 cycles) and $72^{\circ} \mathrm{C}$ for $1 \mathrm{~min}$, then a final elongation step at $72^{\circ} \mathrm{C}$ for $7 \mathrm{~min}$. Fragments of genes encoding RubisCO form I and APS reductase alpha subunit were amplified from each mussel using primers and PCR conditions described in (Blazejak et al., 
2006; Duperron et al., 2007a) and (Deplancke et al., 2000), respectively, using 33 PCR cycles. For these two genes, due to the low amount of PCR product obtained, reactions from the four specimens were pooled together prior to cloning. A fragment of the gene encoding the alpha subunit of particulate methane monooxygenase (pmoA) was amplified from three mussels using primers A189F (5'-GGNGACTGGGACTTCTGG-3') and MB661R (5'CCGGMGCAACGTCYTTACC-3') (Duperron et al., 2007b) with the following cycling conditions: $92^{\circ} \mathrm{C}(4 \mathrm{~min}), 33$ cycles with $92^{\circ} \mathrm{C}(1 \mathrm{~min}), 55^{\circ} \mathrm{C}(1.5 \mathrm{~min})$ and $72^{\circ} \mathrm{C}(1 \mathrm{~min})$, then a final elongation step at $72^{\circ} \mathrm{C}(10 \mathrm{~min})$.

PCR products were purified with the QIAquick PCR purification kit (QIAGEN, Germany) and cloned using the TOPO-TA kit (Invitrogen, California). Inserts from positive clones were partially sequenced using the plasmid-specific primer M13F. A total of $17016 \mathrm{~S}$ rRNA clones and 32 clones per functional gene were partially sequenced and aligned. Chimeric sequences were identified either by visual examination of the alignments or using ChimaeraCheck (Cole et al., 2003) and Bellerophon (Huber et al., 2004). Clones representative of each group of identical sequences were fully sequenced (Table 1).

\section{Sequence analysis and phylogenetic reconstruction}

Sequences were compared to the RDP (Cole et al., 2003) and NCBI (www.ncbi.nlm.nih.gov) databases using BLAST (Altschul et al., 1990). Best hits were included in phylogenetic analysis. Sequences were aligned using ClustalX and alignments were checked manually.

The best fitting model of COI sequence evolution was determined by hierarchical likelihood ratio tests (hLTR) implemented in Modeltest version 3.06 (Posada and Crandall, 1998). The HKY-85 $+[\Gamma]+$ I model of nucleotide evolution was chosen $(I=0.52, \alpha=0.91$, $\mathrm{Ti} / \mathrm{Tv}=5.04)$. Phylogenetic relationships of the COI gene sequence (495 nt) were estimated 
using two methods. First, parameters associated with the HKY model were used in the Maximum Likelihood (ML) heuristic searches with 100 RA replicates. Robustness of the nodes was assessed by performing 1000 bootstrap replicates, TBR branch swapping, and 10 RA replicates. Second, a Bayesian analysis (BA) was performed using MrBayes v3.1.2 (Ronquist and Huelsenbeck, 2003). Two independent analyses were run in parallel using the same parameters as used for the ML searches. The two analyses each comprised four Markov chains and each chain was run over 6.000 .000 generations. Convergence between the two analyses was assessed using likelihood curves, standard deviation of split frequencies, and potential scale reduction factor (PSRF) as indicated by Ronquist (Gelman and Rubin, 1992; Ronquist and Huelsenbeck, 2003).

A general time reversible (GTR) model with $\Gamma$-distributed rates of evolution was employed to analyse the 16S rRNA dataset (1406 nt). RubisCO, APS reductase and pmoA datasets, consisting of alignments of 230, 133 and 154 aminoacids respectively, were analysed using a GTR model. Phylogenetic relationships of the bacterial genes were estimated using MrBayes v3.1.2 by running four Markov chains, each over 500.000 generations. Calculated posterior probablilities are presented as support values for nodes in the trees.

\section{Fluorescence in situ hybridizations (FISH)}

From each mussel, an entire gill was fixed onboard with $2 \%$ formaldehyde in $1 \mathrm{X}$ phosphate-buffered saline (PBS) $\left(4^{\circ} \mathrm{C}, 2-4 \mathrm{~h}\right)$, rinsed 3 times in $1 \mathrm{X}$ PBS, and stored at $-20^{\circ} \mathrm{C}$ in PBS : ethanol (1:1). Back to the lab, tissues were embedded in polyethylene glycol distearate: hexadecanol-1 (9:1) (Duperron et al., 2007b). Sections $7 \mu \mathrm{m}$ thick were cut with a microtome (Leica, Germany), collected on Superfrost ${ }^{\circledR}$ Plus slides (Roth, Germany), rehydrated in decreasing ethanol series, and hybridized as described previously with a buffer containing $40 \%$ formamide (Duperron et al., 2005). 
Three FISH probes, ImedM-138, ImedG-193 and ImedT2-193, were newly designed by modification of previous probes designed for other mussel symbionts (Duperron et al., 2005; Duperron et al., 2007b). These probes target the M1, G and T2 phylotypes, respectively. Three probes from previous studies, Bthio-193, BhecM2-822 (Duperron et al., 2007b) and CF319 (Manz et al., 1996), were used to target phylotypes T1, M2 and CFB (phylum Bacteroidetes), respectively (see table 2 for probe sequences). Dual hybridizations were performed to check that no cross hybridization between probes occured. To check whether some symbionts were missed by our probes, hybridizations using all probes together with the same labelling against Eub338 were performed.

To visualize all symbionts on the same section, combinations of three fluorescent dyes were used. Three probes were labelled each with a single fluorescent dye. For the three other probes, a 1:1 mixture of two mono-labelled probes was used, resulting in symbiont being labelled with both dyes. Three monochrome 8 bits images, one per fluorochrome, were acquired and each image was attributed to either the red, green or blue channel. Images were merged, resulting in a 24 bits RGB image. Displaying composite colors, dual-labelled bacteria can then be distinguished from mono-labelled bacteria (Tab. 2) (Gué, pers. comm.). Images were acquired using a Leica SP5 microscope (Service Imagerie IFR 83 Biologie Intégrative, UPMC) and image treatment was performed using the ImageJ software (Abramoff et al., 2004).

\section{Stable isotope analysis}

Gill and foot tissue of two specimens were acidified overnight in $0.1 \mathrm{~N} \mathrm{HCl}$, rinsed, dessicated for 48 hours in a $46^{\circ} \mathrm{C}$ chamber. Samples were then ground, and stable isotope values of nitrogen and carbon were measured in a Finnigan Delta $\mathrm{S}$ isotope ratio mass 
spectrometer. Tissues from the two individuals were pooled to gather enough material to allow for a reliable measurement. 


\section{Results}

\section{Host phylogeny}

The phylogenetic reconstruction based on the Cyotchrome Oxidase (COI) gene sequence yields Idas macdonaldi and I. washingtonia, two small mussels from the eastern and western coast of the USA respectively (Distel et al., 2000; Jones et al., 2006) as the closest relatives of Idas sp. (Fig. 1). These form a cluster well separated from the three clades which include sequences from Bathymodiolus mussels (Jones et al., 2006). The basal position of $B$. brooksi is not well supported in the BA tree, with a posterior probability of 0.56 , and does not appear in the ML tree; it is thus probably artefactual.

\section{Symbiont diversity and phylogeny based on 16S rRNA gene sequence analysis}

Six distinct phylotypes were recovered in clones libraries obtained from four Idas sp. specimens, in a total of 142 partial (29 full) sequences (Tab. 1). Five phylotypes belong to the Gammaproteobacteria, and one belongs to the phylum Bacteroidetes (Cytophaga Flavobacter Bacteroides or CFB). Among gammaprotebacterial symbionts, three belong to well-known clades of Bathymodiolus-associated symbionts (Fig. 2); M1 is closely related to the methanotrophic symbiont of $B$. brooksi (98.4 \% similarity) (Duperron et al., 2007b); T1 and T2 represent two distinct phylotypes $(97.1 \%$ similarity to each other) clustering within the clade which includes all thiotrophic symbionts of Bathymodiolus mussels and vesicomyids. Phylotype M2 is related to a clone from the Haakon Mosby Mud Volcano (96.8 \% similarity, Lösekann et al. unpublished), and clusters in the same clade as the M2 symbiont from $B$. heckerae (Duperron et al., 2007b). The closest cultivated relatives of this group are free-living methylotrophic bacteria. The last gammaprotebacterial phylotype, $\mathrm{G}$, is related to several clones obtained from marine samples (Bano and Hollibaugh, 2002; Suzuki et al., 2004; 
Brown et al., 2005), and has no related cultivated bacteria. The sixth phylotype, affiliated to the Bacteroidetes group, was identified only once in Idas sp. specimen 1. Its closest relative is clone AL-5 recovered from the gills of the hydrothermal vent shrimp Alvinocaris longirostris (96.0\% similarity; Tokuda et al, unpublished); close relatives also include Polaribacter dokdonensis and an uncultivated Tenacibaculum.

\section{Fluorescence in situ hybridization}

Several to all symbionts co-occur within a single bacteriocyte, mostly in the apical half of the cell (Fig. 3A and Tab. 2). No mutual exclusion between any two symbiont types was observed in dual hybridizations (Fig. 3A-D). Within the apical half of any given bacteriocyte, symbiont types are apparently distributed randomly, and all symbiont types are mixed. The methanotroph-related symbiont M1 was the most abundant bacterium in most bacteriocytes. It displays a typical 'donut' shape under the microscope, likely due to the presence of intracellular stacked membranes typical of Type I methanotrophs as previously observed (Cavanaugh et al., 1987; Duperron et al., 2005).

All symbionts were present in the 4 specimens investigated. The methanotroph-related bacterium M1 was the dominant symbiont in all specimens, all others being, in comparison, much less abundant. The two thiotroph-related symbionts T1 and T2 co-occur, but the density of T2 varied greatly between specimens (Fig. 3B). As for the latest, the density of G varied between specimens, and within a given specimen this bacterium typically occured in aggregates spread over two to three neighbouring bacteriocytes on one side of the gill filament, while it was virtually absent from other bacteriocytes (Fig. 3C). Densities of Bacteroidetes (Fig. 3A,C) and M2 (Fig. 3D) were homogeneous and rather low in all specimens. Control hybridizations using all probes against Eub338 did not yield any bacteria 
hybridized only with Eub338, indicating that we did not miss any abundant symbiont with our set of probes.

\section{RubisCO, APS reductase and pmoA gene sequence analyses}

Two gene sequences encoding a Form IA type of RubisCO were identified, sharing $93.5 \%$ identical amino acid positions (94.8\% sequence similarity in nucleic acids) and $87 \%$ amino acid similarity to the sequence from Hydrogenophilus thermoluteolus, their closest relative in the tree (Fig. 4A). Sequences are only distantly related to the clade comprising RubisCO sequences from symbionts of other molluscs (Lucinoma sp., Solemya velum and Bathymodiolus azoricus) (Schwedock et al., 2004; Spiridonova et al., 2006; Duperron et al., 2007a). However, due to problems in sequencing reactions, many clones yielded sequences of poor quality, so the diversity of RubisCO genes might be underestimated.

Two closely related APS reductase alpha subunit sequences were found. They differ only, but consistently, by three nucleic acid positions among 390 and one amino acid. They cluster together with sequences from Thiobacillus denitrificans ATCC 25259, an environmental clone, and Allochromatium vinosum (posterior probability of 0.99) (Hipp et al., 1997) and are not close relatives to the sequence previously reported from the symbiontassociated clam Lucinoma aff. kazani (Fig. 4B) (Duperron et al., 2007a).

A single $p m o A$ alpha subunit sequence was recovered, displaying $96.8 \%$ similarity to the sequence obtained from the Mid-Atlantic Ridge vent mussel Bathymodiolus azoricus (Spiridonova et al., 2006). This sequence belongs to the group of Type I methanotroph sequences and appears at the base of a well-supported clade containing all but one pmo $\mathrm{A}$ sequences from symbionts of Bathymodiolus species (posterior probability: 0.99) (Fig. 4C) (Duperron et al., 2007b). 


\section{Stable isotope analysis}

Gill tissue from the two pooled specimens displayed a $\delta^{13} \mathrm{C}$ value of $-38.32 \%$ and a $\delta^{15} \mathrm{~N}$ value of $1.00 \%$. Foot tissue displayed values of $-34.04 \%$ and $1.21 \%$, respectively. 


\section{Discussion}

\section{Symbiont diversity and distribution}

Idas sp. harbours the highest diversity of symbionts ever reported for a bivalve, with at least 6 bacterial partners based on 16S rRNA gene sequence analysis and FISH (see Fig. 1). For the past couple decades, large cold seep and hydrothermal vent mussels, mostly from the genus Bathymodiolus, were assumed to harbour only thiotrophs, only methanotrophs, or both types in their gills, dual symbiosis being restricted to Atlantic species (including the Gulf of Mexico) (Cavanaugh et al., 1987; Fisher, 1990; Fisher et al., 1993; Distel et al., 1995; FialaMédioni et al., 2002; Duperron et al., 2005). It was only recently that $B$. heckerae was shown to harbour four symbionts; one methanotroph, two distinct thiotrophs, and a bacterium related to free-living methylotrophs (Duperron et al., 2007b). To a similar set of symbionts, Idas sp. adds two additional, previously unknown, symbionts; one, phylotype G, is related to marine Gammaproteobacteria of unknown metabolism and the other is a Bacteroidetes. The latest is the first example of a member of the phylum Bacteroidetes involved in symbiosis in a chemosynthesis-based ecosystem, though symbiotic Bacteroidetes are known for example in termites (Ohkuma et al., 2002), in beetles (Hurst et al., 1999), in cockroaches (Bandi et al., 1994) and in acanthamoebae (Horn et al., 2001).

The overall morphology of gill filaments and bacteriocytes in Idas sp. is similar to that displayed by Bathymodiolus mussels (Distel et al., 1995). Dominance of methanotrophs over any other symbiont is a common trend in cold seep dual symbiotic Bathymodiolus (Cavanaugh et al., 1987; Fujiwara et al., 2000; Duperron et al., 2005; Duperron et al., 2007b). Symbionts are mixed within bacteriocytes, such as reported for the Mid Atlantic Ridge vent mussels B. azoricus and B. puteoserpentis (Duperron et al., 2006); thiotrophs are not located in the most apical part such as described in other species from the Gulf of Mexico and the 
Gulf of Guinea (Duperron et al., 2005; Duperron et al., 2007b). Compared to B. heckerae, we found no evidence for mutual exclusion between the two thiotrophs, which would contradict the hypothesis of competition between symbionts displaying a similar metabolism. We either did not observe the typical localisation of methylotrophs in the most apical part of bacteriocytes that was described in B. heckerae (Duperron et al., 2007b).

Although we suggest that all symbiont types can occur intracellularly based on the unambiguous occurence of representatives of all phylotypes well inside bacteriocytes on FISH images, the embedding and microscopy techniques used in this study do not allow to conclude definitely about the intra- or extracellular localisation of bacterial symbionts. Preliminary TEM investigations show that although most bacteria occur within host cells, small bacteria also occur right outside bacteriocytes, but it is not yet possible to assign them to any of the $16 \mathrm{~S}$ rRNA phylotypes. Further investigation will assess the identity of these bacteria, because any given symbiont could be present both within and outside of host cells.

\section{Functional aspects of symbiosis in Idas sp.}

Sulphide-oxidizing endosymbionts are reported to harbour APS reductase and RubisCO based on enzymatic activities (Fisher et al., 1987). The presence of two sequences of each gene supports the hypothesis, based on the occurence of two thiotroph-related $16 \mathrm{~S}$ rRNA phylotypes, of two thiotrophic symbionts (T1 and T2) although we can not rule out the hypothesis that phylotype $\mathrm{G}$ also corresponds to a sulphide-oxidizer. If APS reductase is widely acknowledged as a good marker for the presence of bacteria involved in the sulfur cycle, caution is needed with regards to RubisCO as this enzyme is more widespread, and has recently been identified in the 'methanotrophic' endosymbiont of a Bathymodiolus species using coupled 16S rRNA and mRNA FISH (Elsaied et al., 2006), as well as in the genome sequence of the methanotroph Methylococcus capsulatus (Ward et al., 2004). APS sequences 
found in Idas sp. do not cluster together with the lucinid symbiont sequences, but neither do the symbionts in 16S rRNA-based phylogenies (Stewart et al., 2005). The absence of a close relationship between RubisCO sequences and those from other molluscs, especially Bathymodiolus azoricus, is more surprising and questions whether these sequences might originate from another of the symbionts besides $\mathrm{T} 1$ and $\mathrm{T} 2$, or even from a contaminant. The phylogeny of RubisCO is reported to be inconsistant with phylogenies obtained from classical markers due to multiple events of horizontal gene transfer and duplication, and thus RubisCO trees are not always reliable (Delwiche and Palmer, 1996; Uchino and Yokota, 2003). It is illustrated in our tree, which displays a betaproteobacterium, Hydrogenophilus thermoluteolus, as the closest relative to the Idas sp. sequences. More data is thus needed before one can really investigate the phylogeny of these two genes in bathymodiolines and compare it to $16 \mathrm{~S}$ rRNA-based trees. Particulate methane monooxygenase, of which the pmo $A$ gene encodes the alpha subunit, has only been reported in methanotrophic bacteria. The existence of a clade comprising pmoA sequences from Bathymodiolus-associated methanotrophs supports the hypothesis that true methanotrophs, represented by phylotype M1, occur as symbionts in Idas sp. and that methanotrophic symbionts of mussels have a common evolutionary origin. Overall, more work is needed to unambiguously associate each 16S rRNA phylotype with eventual corresponding functional gene sequences, especially in the present case where Idas sp. shelters 6 distinct symbionts.

The presence of RubisCO-, APS reductase- and particulate methane monooxygenaseencoding genes suggests that the symbiont population has the genetic potential to perform autotrophy, sulphide oxidation and methanotrophy, in a way similar to that observed in dual symbiotic Bathymodiolus (Fisher, 1990). Whether these genes are expressed in the Idas sp. symbiosis remains to be determined, for example using coupled $16 \mathrm{~S}$ rRNA and mRNA hybridization techniques (Elsaied et al., 2006). However, the occurence of several highly 
similar copies of APS reductase and RubisCO might render their distinction impossible due to the use of polynucleotidic probes (Elsaied et al., 2006).

The $\delta^{13} \mathrm{C}$ value of $-38.32 \%$ measured from gill tissue is between values measured in vent Bathymodiolus species (-21 to $-37 \%$ ) and values measured in cold seep species $(-39.7$ to $-74.7 \%$ ) and thus consistent with the hypothesis of a nutrition based on chemoautotrophy and methanotrophy, although signatures of local carbon sources were not measured (Cavanaugh et al., 1987; Trask and Van Dover, 1999; Colaco et al., 2002; MacAvoy et al., 2002). The presence of thermogenic, thus heavier, methane in the 'Central Province' could explain these intermediate values (Bayon et al., submitted). Another possibility is the significant contribution of non-methane carbon sources, either by other symbionts or by filterfeeding. The methylotroph-related symbiont might be fixing $\mathrm{C} 1$ compounds present in the environment, or the CFB (Bacteroidetes) symbiont might be acquiring organic carbon heterotrophically, as do many bacteria from this phylum including its relative Polaribacter dokdonensis (Gosink et al., 1998).

\section{Comparison with Bathymodiolus symbioses and evolutionary implications}

The colonisation of cold seeps and hydrothermal vents by symbiont-bearing mussels is hypothesised to have occured through 'intermediate' forms inhabiting sunken woods or organic debris, of which Idas and other small mussels may be actual representatives (Distel et al., 2000). These small mussels are thus good models to investigate the evolution of symbiosis in mytilids, which led to the highly specialized Bathymodiolus-like mussels found today only at cold seeps and hydrothermal vents.

The phylogenetic position of Idas sp., related to two Idas species and well-separated from representatives of the genus Bathymodiolus, confirms the claim based on morphological features that this mussel is a 'true' Idas. The occurence of 6 bacterial symbionts was 
unexpected, as bathymodioline mussels are usually reported to possess only one or two symbionts. Another mussel, B. heckerae, was recently shown to harbour 4 bacteria (Duperron et al., 2007b). The fact that Idas sp. and B. heckerae, which are only distantly related, both harbour two thiotrophic, one methanotrophic and one Methylophaga-related symbionts is intriguing (see Fig. 1). It could result from a functional convergence linked to the occurrence of both species in cold seep habitats. However, an alternative hypothesis would be that the most recent common ancestor of Idas and Bathymodiolus had multiple symbionts, some of which were lost in other mytilid species, or were overseen by investigators. Indeed, the identification of symbionts relies upon PCR amplification and cloning, a procedure known to lead to underestimates of gene diversity because of faster amplification of certain sequences and to the examination of a limited number of clones (Qiu et al., 2001). Decreasing the number of PCR cycles and increasing the number of clones reduce these biases, but this has not been done systematically in mussel symbiosis studies. It is thus very likely that molecular studies, as well as morphological studies, have underestimated the true diversity of symbionts and that multiple symbioses involving both sulphide- and methane-oxidizing but also other types of symbionts are much more widespread than previously thought in bathymodiolinae.

Two symbionts, the gammaproteobacterial phylotype $G$ and the Bacteroidetes phylotype, belong to groups not previously reported in symbiosis with mytilids. Considering the latest, many members of the phylum Bacteroidetes are known to degrade plant polymers such as cellulose (Madigan et al., 2002). As many Idas and related species occur on sunken woods (Distel et al., 2000; Baco and Smith, 2003; Pailleret et al., 2007), the presence of CFB symbionts could correspond to a specific adaptation to such environments. Because the Bacteroidetes phylum also comprises many pathogens, an alternative hypothesis consistent with the presence of localized CFB aggregates on gill sections would be that Idas sp. is being infected by pathogenic bacteria. 
The phylogenetic tree of thiotroph- and methanotroph-related symbionts, for which 16S rRNA sequences are available from numerous Bathymodiolus species, does not display the same branching order as the host tree presented in this and previous studies. In particular, sequences from Idas sp. symbionts are not basal to Bathymodiolus sequences, while some host-based studies support the position of Idas as an outgroup to Bathymodiolus (Iwasaki et al., 2006; Jones et al., 2006). Cladogenesis is clearly not simultaneous between hosts and symbionts, there is thus no compelling evidence for host-symbiont co-speciation, contrary to what is observed in vesicomyid clams (Peek et al., 1998). This observation is consistent with the hypothesis of environmental transmission proposed by Won et al. for the sulphideoxidizing symbionts based on the analysis of bacterial Internal Transcribed Spacer genes in $B$. azoricus and B. puteoserpentis from the mid-Atlantic Ridge (Won et al., 2003). How methanotrophic symbionts are transmitted is not yet elucidated.

Idas sp. is the first small Bathymodiolus-related mussel in which symbiosis was investigated using molecular techniques. Features such as gill structure, symbiont localisation or metabolic potential are shared with some bathymodioline mussels, but the high diversity of symbionts is intriguing. Large scale studies based on numerous species and large clone libraries would help understanding how multiple symbioses established, and whether it is the ancestral or derived state of symbiosis. We suggest that symbiosis evolved because hosts epithelial cells became "permeable" to certain types of bacteria. The origin of this permeability could be a change in host defense systems, or the presence of appropriate virulence genes in some bacteria, which might have been pathogens or parasites in the beginning. The fact that several bacterial lineages occur in symbiosis raises questions about how bacteria become symbionts. Further work should aim at understanding which genes are 
needed to communicate with, enter, and survive within the host tissue, and whether these genes were eventually laterally transmitted between bacterial lineages.

\section{$\underline{\text { Acknowledgments }}$}

We thank the crew and pilots of RV L'Atalante and submersible Nautile, as well as the Nautinil scientific party led by chief scientist J. P. Foucher for their help onboard. We thank V. Georget at the Service Imagerie IFR 83 Biologie Intégrative (UPMC), E. Roussel and V. Cueff Gauchard (Ifremer) for technical assistance. We thank the two reviewers for helpful comments. Support from funding agencies is gratefully ackowledged: EU progams Mediflux (Nautinil cruise) and Hermes (labwork, CT 511234); S.D. is funded by UPMC and Ifremer; J.L. is funded by a grant from the graduate school Diversité du Vivant (UPMC); S.H. has a grant from the EU network of excellence REX-3DEM (CT 502828). 
Abramoff, M.D., Magelhaes, P.J., and Ram, S.J. (2004) Image processing with ImageJ. Biophotonics International 11: 36-42.

Altschul, S.F., Gish, W., Miller, W., Myers, E.W., and Lipman, D.J. (1990) Basic local alignment search tool. Mol. Biol. 215: 403-410.

Baco, A.R., and Smith, C.R. (2003) High species richness in deep-sea-chemoautotrophic whale skeleton communities. Mar. Ecol. Prog. Ser. 260: 109-114.

Bandi, C., Damiani, G., Magrassi, L., Grigolo, A., Fani, R., and Sacchi, L. (1994)

Flavobacteria as intracellular symbionts in cockroaches. Proc. R. Soc. Lond. B. Biol. Sci. 257: $43-48$.

Bano, N., and Hollibaugh, J.T. (2002) Phylogenetic composition of bacterioplankton assemblages from the Arctic Ocean. Appl. Environ. Microbiol. 68: 505-518.

Bayon, G., Loncke, L., Dupré, S., Caprais, J.C., Ducassou, E., Duperron, S. et al. (submitted) In situ investigation of the Centre Nile margin: linking fluid seepage and continental-slope instabilities.

Blazejak, A., Kuever, J., Erseus, C., Amann, R., and Dubilier, N. (2006) Phylogeny of 16S rRNA, ribulose 1,5-bisphosphate carboxylase/oxygenase, and adenosine 5'-phosphosulfate reductase genes from gamma- and alphaproteobacterias symbionts in gutless marine worms (Oligochaeta) from Bermuda and the Bahamas. Appl. Environ. Microbiol. 72: 5527-5536. Bolotin, J., Hrs-Brenko, M., Tutman, P., Glavic, N., Kozul, V., Skaramuca, B. et al. (2005) First record of Idas simpsonii (Mollusca: Bivalvia: Mytilidae) in the Adriatic Sea. J. Mar. Biol. Ass.UK 85: 977-978.

Brown, M.W., Schwalbach, M.S., Hewson, I., and Fuhrman, J.A. (2005) Coupling 16S-ITS rDNA clone libraries and ARISA to show marine microbial diversity: development and application to a time series. Environ. Microbiol. 7: 1466-1479. 
Cavanaugh, C.M., Levering, P.R., Maki, J.S., Mitchell, R., and Lidstrom, M.E. (1987)

Symbiosis of methylotrophic bacteria and deep-sea mussels. Nature 325: 346-347.

Colaço, A., Dehairs, F., Desbruyères, D., Le Bris, N., and Sarradin, P.M. (2002) $\delta^{13}$ C

signature of hydrothermal mussels is related with the end-member fluid concentration of $\mathrm{H}_{2} \mathrm{~S}$ and $\mathrm{CH}_{4}$ at the Mid-Atlantic Ridge hyderothermal vent fields. Cah. Biol. Mar. 43: 259-262.

Cole, J.R., Chai, B., Marsh, T.L., Farris, R.J., Wang, Q., Kulam, S.A. et al. (2003) The Ribosomal Database Project (RDP-II): previewing a new autoaligner that allows regular updates and the new prokaryotic taxonomy. Nucl. Acids Res 31: 442-443.

DeChaine, E.G., and Cavanaugh, C.M. (2005) Symbioses of methanotrophs and deep-sea mussels (Mytilidae: Bathymodiolinae). In Molecular Basis of Symbiosis. Overmann, J. (ed): Springer-Verlag, pp. 227-249.

DeChaine, E.G., Bates, A.E., Shank, T., and Cavanaugh, C.M. (2006) Off-axis symbiosis found: characterization and biogeography of bacterial symbionts of Bathymodiolus mussels from Lost City hydrothermal fields. Environ. Microbiol. 8: 1902-1912.

Delwiche, C.F., and Palmer, J.D. (1996) Rampant horizontal transfer and duplication of RubisCO genes in eubacteria and plastids. Mol. Biol. Evol. 13: 873-882.

Deming, J.W., Reysenbach, A.L., Macko, S.A., and Smith, C.R. (1997) Evidence for the microbial basis of a chemoautotrophic invertebrate community at a whale fall on the deep seafloor: bone-colonizing bacteria and invertebrate endosymbionts. Miscrosc. Res. Tech. 37: 162-170.

Deplancke, B., Hristova, K.R., Oakley, H.A., McCracken, V.J., Aminov, R., Mackie, R.I., and Gaskins, H.R. (2000) Molecular Ecological Analysis of the Succession and Diversity of Sulfate-Reducing Bacteria in the Mouse Gastrointestinal Tract. Appl. Environ. Microbiol. 66: $2166-2174$ 
Distel, D.L., Baco, A., Chuang, E., Morrill, W., Cavanaugh, C., and Smith, C. (2000) Do mussels take wooden steps to deep-sea vents? Nature 403: 725-726.

Distel, D.L., and Cavanaugh, C.M. (1994) Independent phylogenetic origins of methanotrophic and chemoautotrophic bacterial endosymbioses in marine bivalves. $J$. Bacteriol. 176: 1932-1938.

Distel, D.L., Lane, D., Olsen, G., Giovannoni, S., Pace, B., Stahl, D., and Felbeck, H. (1988) Sulfur-oxidizing bacterial endosymbionts - Analysis of phylogeny and specificity by $16 \mathrm{~S}$ ribosomal RNA sequences. J. Bacteriol. 170: 2506 - 2510.

Distel, D.L., Lee, H.K.W., and Cavanaugh, C.M. (1995) Intracellular coexistence of methanoand thioautotrophic bacteria in a hydrothermal vent mussel. Proc. Natl. Acad. Sci. USA 92: 9598-9602.

Duperron, S., Fiala-Médioni, A., Caprais, J.C., Olu, K., and Sibuet, M. (2007a) Evidence for chemoautotrophic symbiosis in a Mediterranean cold seep clam (Bivalvia: Lucinidae): comparative sequence analysis of bacterial 16S rRNA, APS reductase and RubisCO genes. FEMS Microbiol. Ecol. 59: 64-70.

Duperron, S., Sibuet, M., MacGregor, B.J., Kuypers, M.M., Fisher, C.R., and Dubilier, N. (2007b) Diversity, relative abundance, and metabolic potential of bacterial endosymbionts in three Bathymodiolus mussels (Bivalvia: Mytilidae) from cold seeps in the Gulf of Mexico. Environ. Microbiol. 9: 1423-1438.

Duperron, S., Nadalig, T., Caprais, J.C., Sibuet, M., Fiala-Médioni, A., Amann, R., and Dubilier, N. (2005) Dual symbiosis in a Bathymodiolus mussel from a methane seep on the Gabon continental margin (South East Atlantic): 16S rRNA phylogeny and distribution of the symbionts in the gills. Appl. Environ. Microbiol. 71: 1694-1700.

Duperron, S., Bergin, C., Zielinski, F., McKiness, Z.P., DeChaine, E.G., Cavanaugh, C.M., and Dubilier, N. (2006) A dual symbiosis shared by two mussel species, Bathymodiolus 
azoricus and B. puteoserpentis (Bivalvia: Mytilidae), from hydrothemal vents along the northern Mid-Atlantic Ridge. Environ. Microbiol. 8: 1441-1447.

Elsaied, H.E., Kaneko, R., and Naganuma, T. (2006) Molecular characterization of a deep-sea methanotrophic mussel symbiont that carries a RuBisCO gene. Mar. Biotechnol. 8: 511-520. Fiala-Médioni, A., McKiness, Z.P., Dando, P., Boulegue, J., Mariotti, A., Alayse-Danet, A.M. et al. (2002) Ultrastructural, biochemical and immunological characterisation of two populations of he Mytilid mussel Bathymodiolus azoricus from the Mid Atlantic Ridge: evidence for a dual symbiosis. Mar. Biol. 141: 1035-1043.

Fisher, C.R. (1990) Chemoautotrophic and methanotrophic symbioses in marine invertebrates. Rev. Aquat. Sci. 2: 399-613.

Fisher, C.R., Childress, J.J., Oremland, R.S., and Bidigare, R.R. (1987) The importance of methane and thiosulphate in the metabolism of the bacterial symbionts of two deep-sea mussels. Mar. Biol. 96: 59-71.

Fisher, C.R., Brooks, J.M., Vodenichar, J.S., Zande, J.M., Childress, J.J., and Burke Jr., R.A. (1993) The co-occurence of methanotrophic and chemoautotrophic sulfur oxydixing bacterial symbionts in a deep-sea mussel. P. S. Z. N. I: Mar Ecol 14: 277-289.

Folmer, O., Black, M.B., Hoeh, W.R., Lutz, R.A., and Vrijenhoek, R.C. (1994) DNA primers for amplification of mitochondrial cytochrome C oxidase subunit I from metazoan invertebrates. Mol. Mar. Biol. Biotechnol. 3: 294-299.

Fujiwara, Y., Takai, K., Uematsu, K., Tsuchida, S., Hunt, J.C., and Hashimoto, J. (2000)

Phylogenetic characterization of endosymbionts in three hydrothermal vent mussels: influence on host distribution. Mar. Ecol. Prog. Ser. 208: 147-155.

Gelman, A., and Rubin, D. (1992) Inference from iterative simulation using multiple sequenes. Stat. Sci. 7: 817-818. 
Gosink, J.J., Woese, C.R., and Staley, J.T. (1998) Polaribacter gen. nov. with three new species, $P$. irgensii sp. nov., $P$. franzmannii sp. nov. and $P$. filamentus sp. nov., gas vacuolate polar marine bacteria of the Cytophaga-Flavobacterium-Bacteroides groups and reclassification of 'Flectobacillus glomeratus' as Polaribacter glomeratus comb. nov. Int. J. Syst. Bacteriol. 48: 223-235.

Gustafson, R., Turner, R., Lutz, R., and Vrijenhoek, R. (1998) A new genus and five new species of mussels (Bivavlia, Mytilidae) from deep-sea sulfide/hydrocarbon seeps in the Gulf of Mexico. Malacologia 40: 63-112.

Hipp, W.M., Pott, A.S., Thum-Schmitz, N., Faath, I., Dahl, C., and Truper, H. (1997) Towards the phylogeny of APS reductases and sirohaem sulfite reductases in sulfate-reducing and sulfide-oxidizing prokaryotes. Microbiology 143: 2891-2902.

Horn, M., Harzeneter, M., Linner, T., Scmid, E.N., Müller, K.D., Michel, R., and Wagner, M. (2001) Members of the Cutophaga-Flavobacterium-Bacteroides phylum as intracellular bacteria in acanthamoebae: proposal of 'Candidatus Amoebophilus asiaticus'. Environ. Microbiol. 3: 440-449.

Huber, T., Faulkner, G., and Hugenholtz, P. (2004) Bellerophon; a program to detect chimeric sequences in multiple sequence alignments. Bioinformatics 20: 2317-2319.

Hurst, G.D., Bandi, C., Sacchi, L., Cochrane, A.G., Betrtrand, D., Karaca, I., and Majerus, M.E. (1999) Adonia variegata (Coleoptera: Coccinellidae) bears maternally inherited flavobacteria that kill males only. Parasitology 118: 125-134.

Iwasaki, H., Kyuno, A., Shintaki, M., Fujita, Y., Fujiwara, Y., Fujikura, K. et al. (2006) Evolutionary relationships of deep-sea mussels inferred by mitochondrial DNA sequences. Mar. Biol. 149: 1111-1122.

Jones, W.J., Won, Y.J., Maas, P.A.Y., Smith, P.J., Lutz, R.A., and Vrijenhoek, R.C. (2006) Evolution of habitat use by deep-sea mussels. Mar. Biol. 148. 
MacAvoy, S.E., Macko, S.A., and Joye, S.B. (2002) Fatty acid carbon isotope signatures in chemosynthetic mussels and tubeworms from Gulf of Mexico hydrocarbon seep communities. Chem. Geol. 185: 1-8.

Madigan, M.T., Martinko, J.M., and Parker, J. (2002) Brock Biology of Microorganisms: Pearson Education.

Manz, W., Amann, R., Ludwig, W., Vancanneyt, M., and Schleifer, K.H. (1996) Application of a suite of 16S rRNA-specific oligonucleotide probes designed to investigate bacteria of the phylum Cytophaga-Flavobacter-Bacteroides in the natural environment. Microbiology 142: 1097-1106.

Ohkuma, M., Noda, S., Hongoh, Y., and Kudo, T. (2002) Diverse bacteria related to the Bacteroides subgroup of the CFB phylum within the gut symbiotic communities of various termites. Biosci. Biotechnol. Biochem. 66: 78-84.

Olu-LeRoy, K., Sibuet, M., Fiala-Médioni, A., Gofas, S., Salas, C., Mariotti, A. et al. (2004) Cold seep communities in the deep eastern Mediterranean Sea: composition, symbiosis, and spatial distribution on mud volcanoes. Deep-Sea Res. I 51: 1915-1936.

Pailleret, M., Haga, T., Petit, P., Privé-Gill, C., Saedlou, N., Gaill, F., and Zbinden, M. (2007) Sunken woods from the Vanuatu islands: identification of wood substrates and preliminary description of associated fauna. Mar. Ecol. 27: 1-9.

Peek, A.S., Feldman, R.A., Lutz, R.A., and Vrijenhoek, R.C. (1998) Cospeciation of chemoautotrophic bacteria and deep sea clams. Proc. Natl. Acad. Sci. USA 95: 9962 - 9966. Posada, D., and Crandall, K.A. (1998) MODELTEST: testing the model of DNA substitution. Bioinformatics application note 14: 817-818.

Qiu, X., Wu, L., Huang, H., McDonel, P., Palumbo, A.V., Tiedje, J.M., and Zhou, J. (2001) Evaluation of PCR-generated chimaeras, mutations, and heteroduplexes with 16S rRNA genebased cloning. Appl. Environ. Microbiol. 67: 880-887. 
Ronquist, F., and Huelsenbeck, J.P. (2003) MRBAYES 3: Bayesian phylogenetic inference under mixed models. Bioinformatics 19: 1572-1574.

Schwedock, J., Hermer, T.L., Scott, K.M., Hektor, H.J., Seitz, A.P., Fontana, M.C. et al. (2004) Characterization and expression of genes from the RubisCO gene cluster of the chemoautotrophic symbiont of Solemya velum: cbbLSQO. Arch. Microbiol. 182: 18-29. Spiridonova, E.M., Kuznetsov, B.B., Pimenov, N.V., and Tourova, T.P. (2006) Phylogenetic characterization of endosymbionts of the hydrothermal vents mussel Bathymodiolus azoricus by analysis of the $16 \mathrm{~S}$ rRNA, cbbL, and pmoA genes. Microbiology 75: 798-806.

Stewart, F.J., Newton, L.G., and Cavanaugh, C.M. (2005) Chemosynthetic endosymbioses: adaptations to oxic-anoxic interfaces. Trends Microbiol. 13: 439-448.

Suzuki, M.T., Preston, C.M., Beja, O., de le Torre, J.R., Steward, G.F., and DeLong, E.F. (2004) Phylogenetic screening of ribosomal RNA gene-containing clones from Bacterial Artificial Chromosome (BAC) libraries from different depths in Monterey Bay. Microb. Ecol. 48: $473-488$.

Trask, J.L., and Van Dover, C.L. (1999) Site-specific and ontogenetic variations in nutrition of mussels (Bathymodiolus sp.) from the Lucky Strike hydrothermal vent field, Mid-Atlantic Ridge. Limnol. Oceanogr. 44: 334-343.

Uchino, Y., and Yokota, A. (2003) 'Green-like' and 'Red-like' RubisCO cbbL genes in Rhodobacter azotoformans. Mol. Biol. Evol. 20: 821-830.

Von Cosel, R. (2002) A new species of bathymodioline mussel (Mollusca, Bivalvia, Mytilidae) from Mauritania (West Africa), with comments on the genus Bathymodiolus Kenk \& Wilson, 1985. Zoosystema 24: 259 - 271.

Ward, N., Larsen, O., Sakwa, J., Bruseth, L., Khouri, H., Durkin, A.S. et al. (2004) Genomic insights into methanotrophy: the complete genome sequence of Methylococcus capsulatus (Bath). PLoS Biol. 2: E303. 
Won, Y.J., Hallam, S.J., O'Mullan, D., Pan, I.L., Buck, K.R., and Vrijenhoek, R.C. (2003)

Environmental acquisition of thiotrophic endosymbionts by deep-sea mussels of the genus Bathymodiolus. Appl. Environ. Microbiol. 69: 6785-6792. 


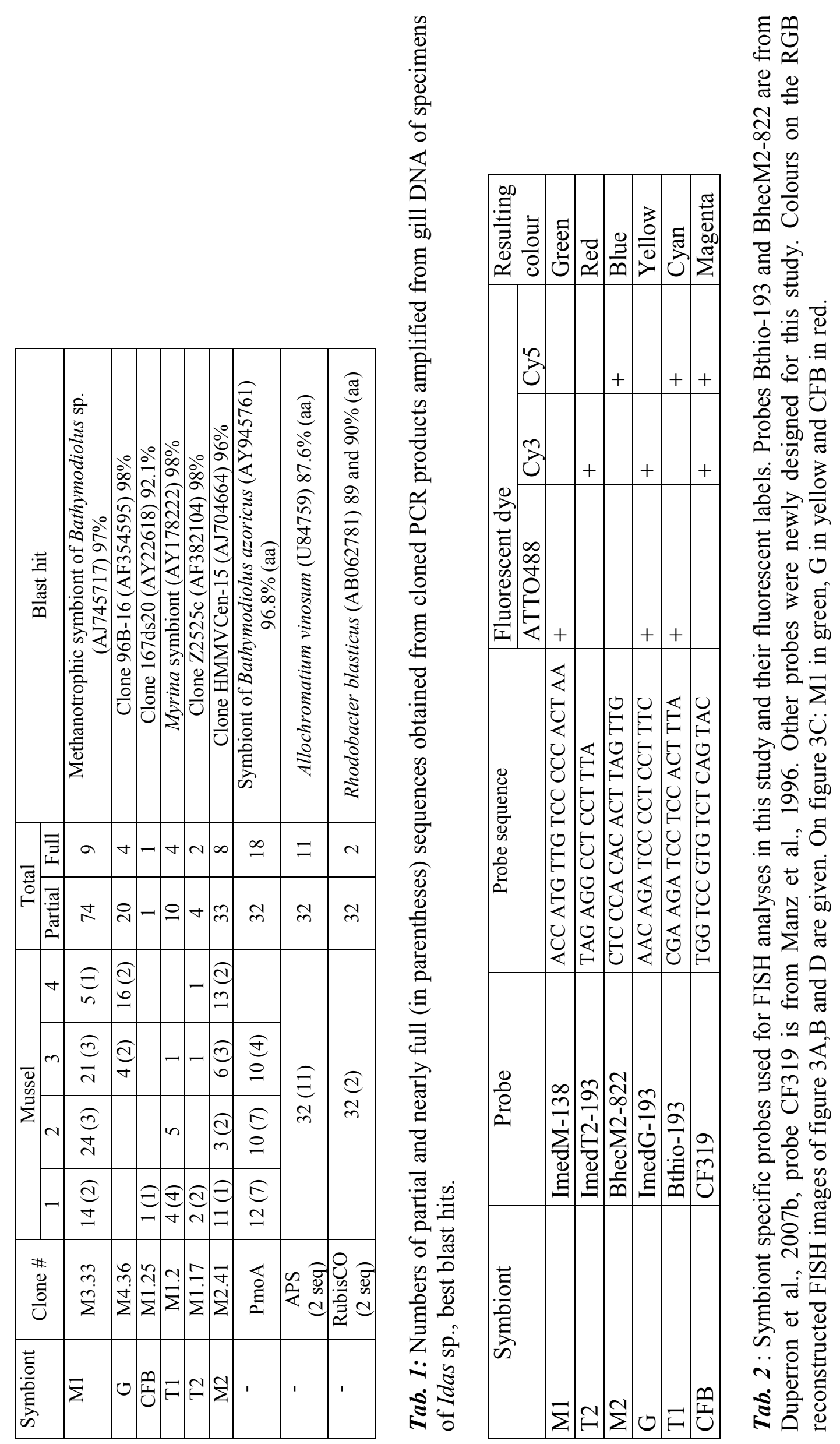




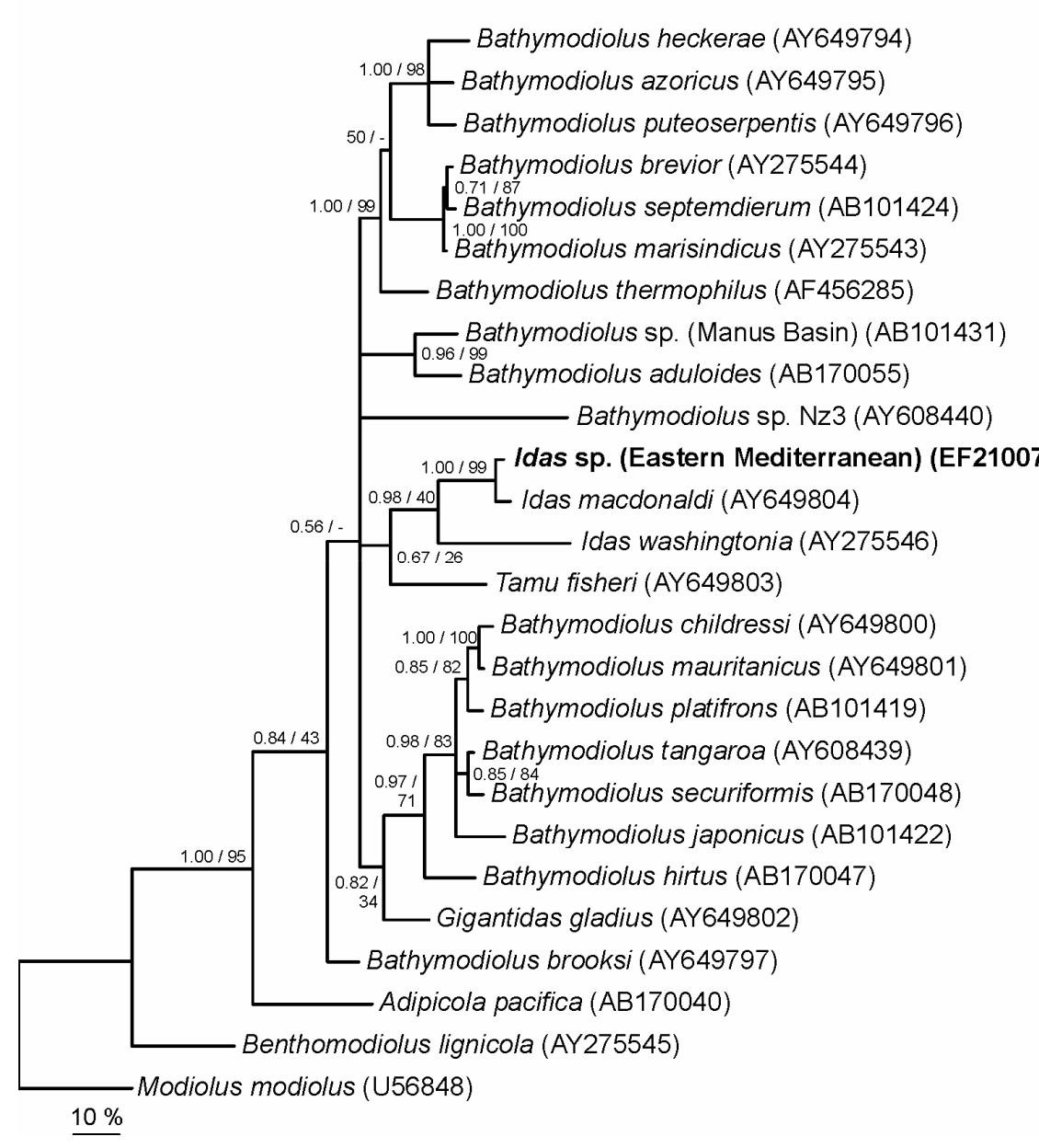

Mol. M1 M2 T1 T2 G CFB

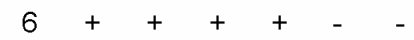

$5+-+\ldots-$

$3+-+\ldots+-$

- $-\quad-\quad+\quad-\quad-$

4 - $-+\quad-\quad-$

- $-\quad+\quad-\quad-$

1

$\mathrm{Nd}$

$\mathrm{Nd}$

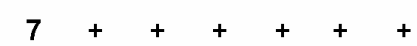

Nd

$\mathrm{Nd}$

2

$\mathrm{Nd}$

4

Nd

Nd

$4+-\quad-\quad-\quad-\quad-$

$\mathrm{Nd}$

$\mathrm{Nd}$

$6+-+-\quad-$

$\mathrm{Nd}$

$\mathrm{Nd}$

Fig. 1: Tree displaying the phylogenetic relationship between Idas sp. and other bathymodiolinae, putatively harbouring bacterial symbionts, based on the analysis of the cytochrome oxidase subunit I gene. Modiolus modiolus is used as an outgroup. Values at nodes indicate posterior probabilities (Bayesian) / boostrap values (maximum likelihood). Scale bar represents $10 \%$ estimated base substitution. Columns indicate the presence/absence of symbionts within the gill tissue: methanotroph (M1), methylotroph-related (M2), thiotroph (T1), second thiotroph (T2), symbiont G-related (G) and Bacteroidetes (CFB). Column Mol. refers to the following molecular studies: Distel et al., 1988 (1); Distel et al., 1994 (2); Distel et al., 1995 (3); Fujiwara et al., 2000 (4); Duperron et al., 2006 (5); Duperron et al., 2007b (6); This study (7); No molecular data available, but other evidence exist such as TEM or enzyme assays (-); No data available regarding symbiosis in the species (Nd). 


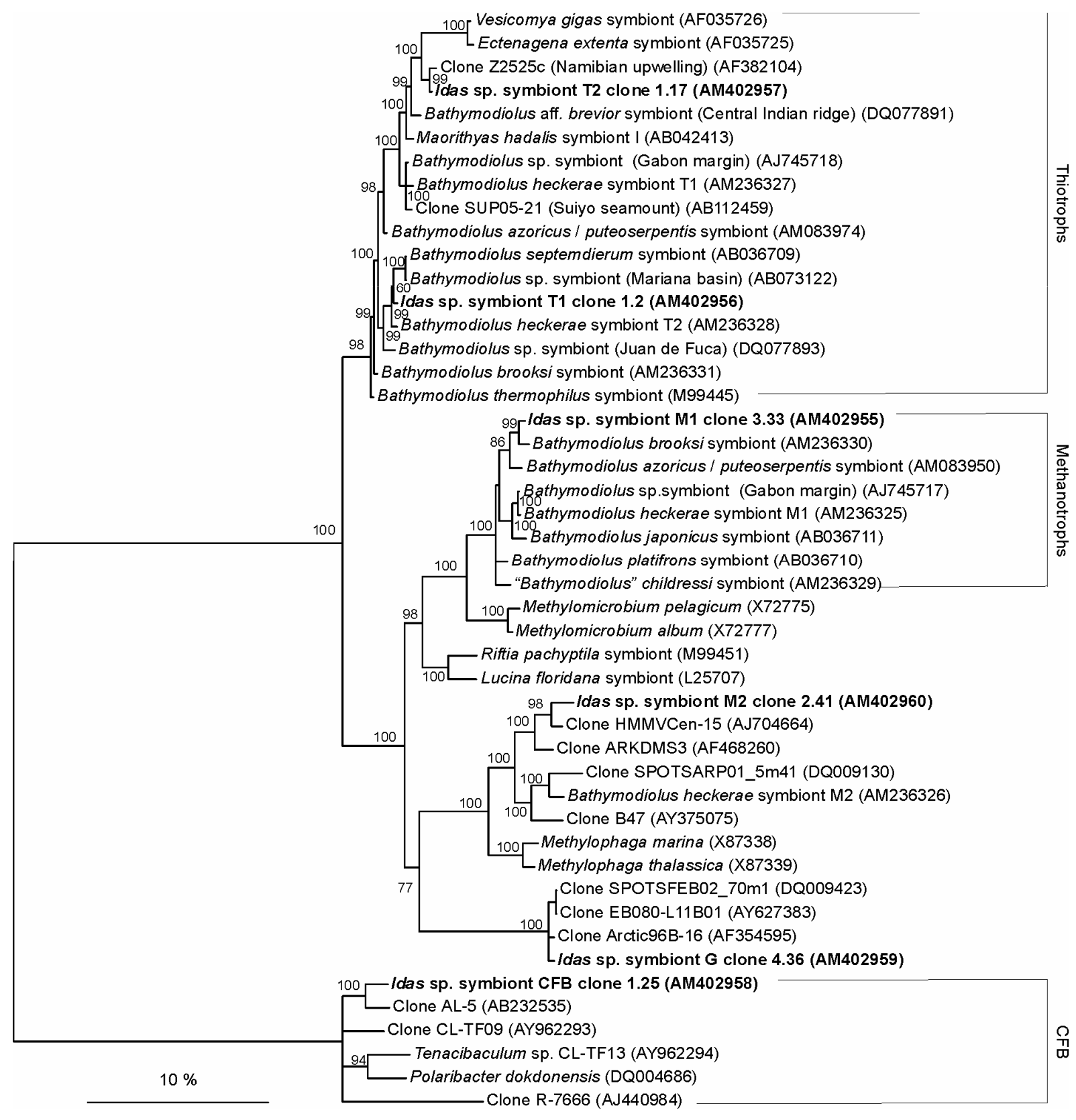

Fig. 2: Phylogenetic tree displaying bacterial symbionts associated with Idas sp. based on $16 \mathrm{~S}$ rRNA gene sequences (in bold). Bacteroidetes (CFB) are used as an outgroup to the Gammaproteobacteria. Posterior probabilities are displayed as percentages ( $>60 \%$ shown). Scale bar represents $10 \%$ estimated base substitution. 

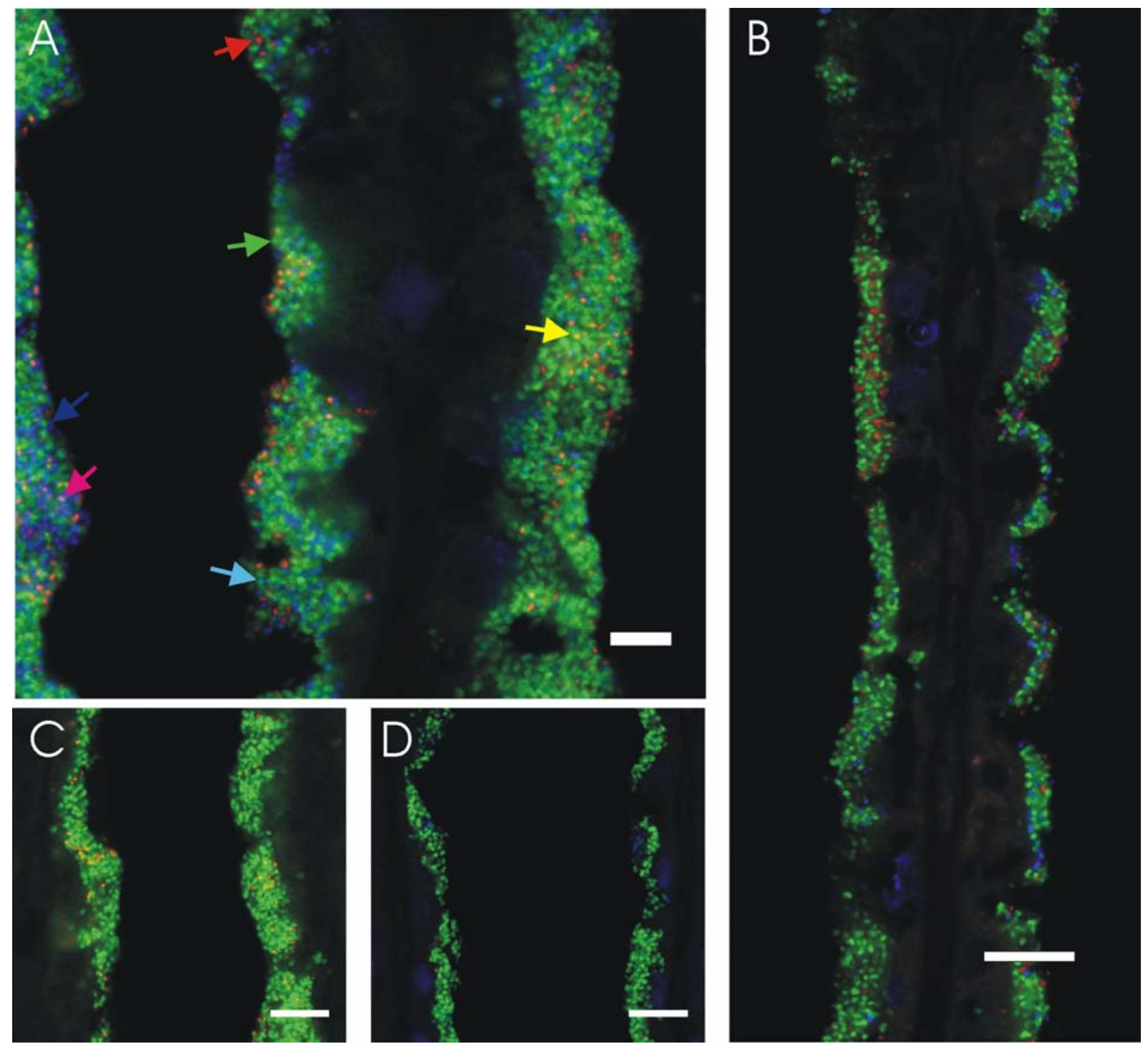

Fig. 3: Fluorescence in situ hybridization of symbiotic bacteria on transversal sections of gill filaments of Idas sp. For color code, refer to table 2. A: Hybridization displaying all 6 symbionts on a single section. Arrows indicate examples of bacteria displaying the different colors corresponding to color code. Scale bar $=5 \mu \mathrm{m}$. B: Hybridization displaying the distribution of the two sulphide-oxiding symbionts ( $\mathrm{T} 1$ in cyan, $\mathrm{T} 2$ in red) versus the methanotrophic symbiont M1 (in green). Scale bar $=10 \mu \mathrm{m}$. $\boldsymbol{C}$ : Hybridization showing the distribution of symbionts $\mathrm{G}$ (in yellow) and CFB (in red on this image, in magenta on fig. $3 \mathrm{~A}$ ), very few cells visible, one is in the upper right) versus the methanotrophic symbiont M1 (in green). Scale bar $=10 \mu \mathrm{m}$. D: Hybridization showing the distribution of the methylotrophic symbiont M2 (in blue) versus the methanotrophic symbiont M1 (in green). Scale bar $=10 \mu \mathrm{m}$. 


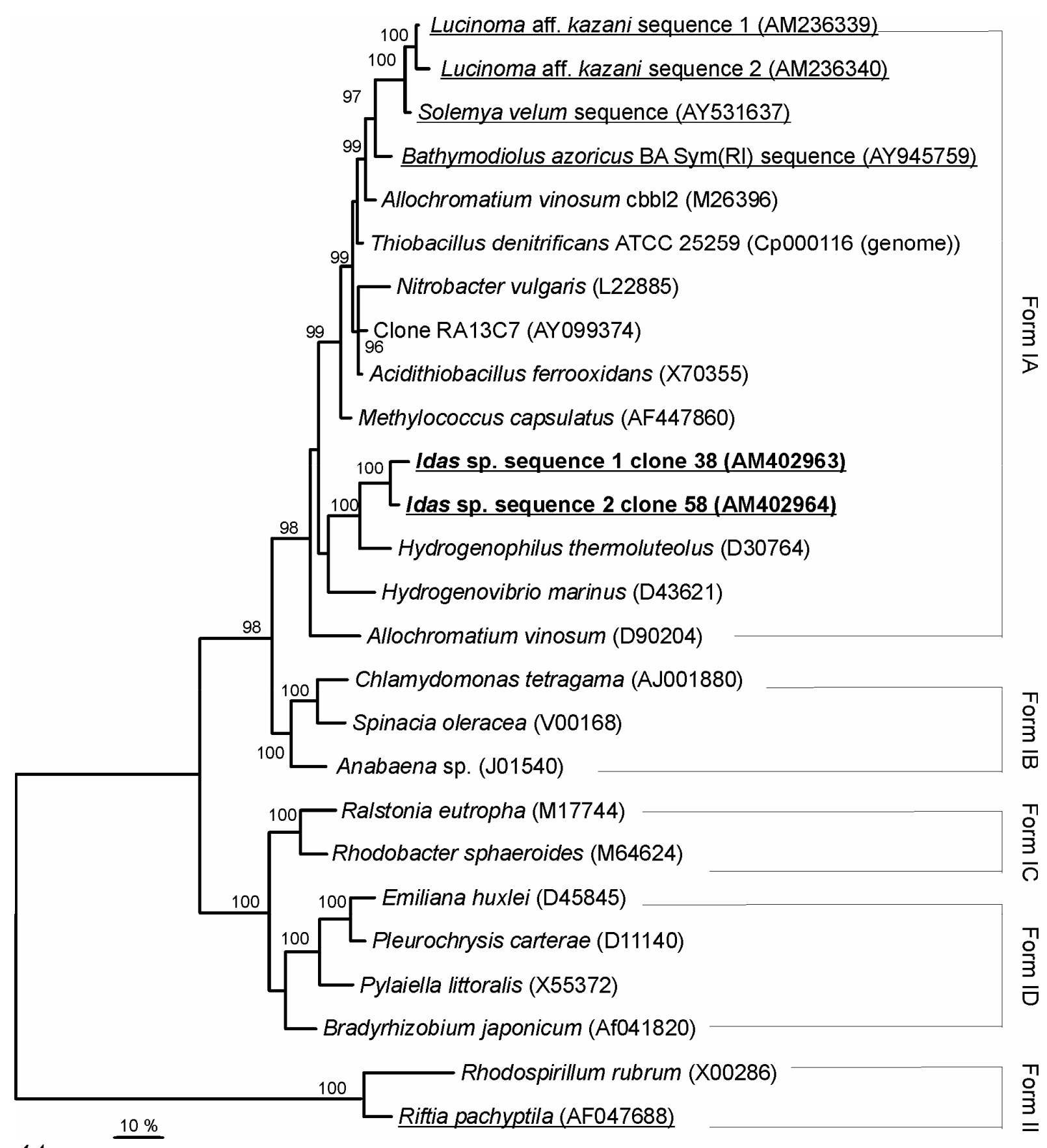

$4 A$

Fig. 4: Phylogenetic trees of functional genes recovered from Idas sp. (in bold). Sequences obtained from symbiont-associated metazoans are underlined. Posterior probabilities $>60 \%$ are shown. Scale bars represent $10 \%$ estimated aminoacid substitution. $A$ : RubisCO phylogenetic tree. Form II RubisCO was used as an outgroup. B: Tree obtained for the APS reductase gene fragment, with $\mathrm{CysH}$ used as an outgroup. $\boldsymbol{C}$ : Tree based on the analysis of a fragment of particulate methane monooxygenase. Sequences from Type II methanotrophs (Alphaproteobacteria) are used as an outgroup. Probable source organism for the pmoA sequence is symbiont M1. 


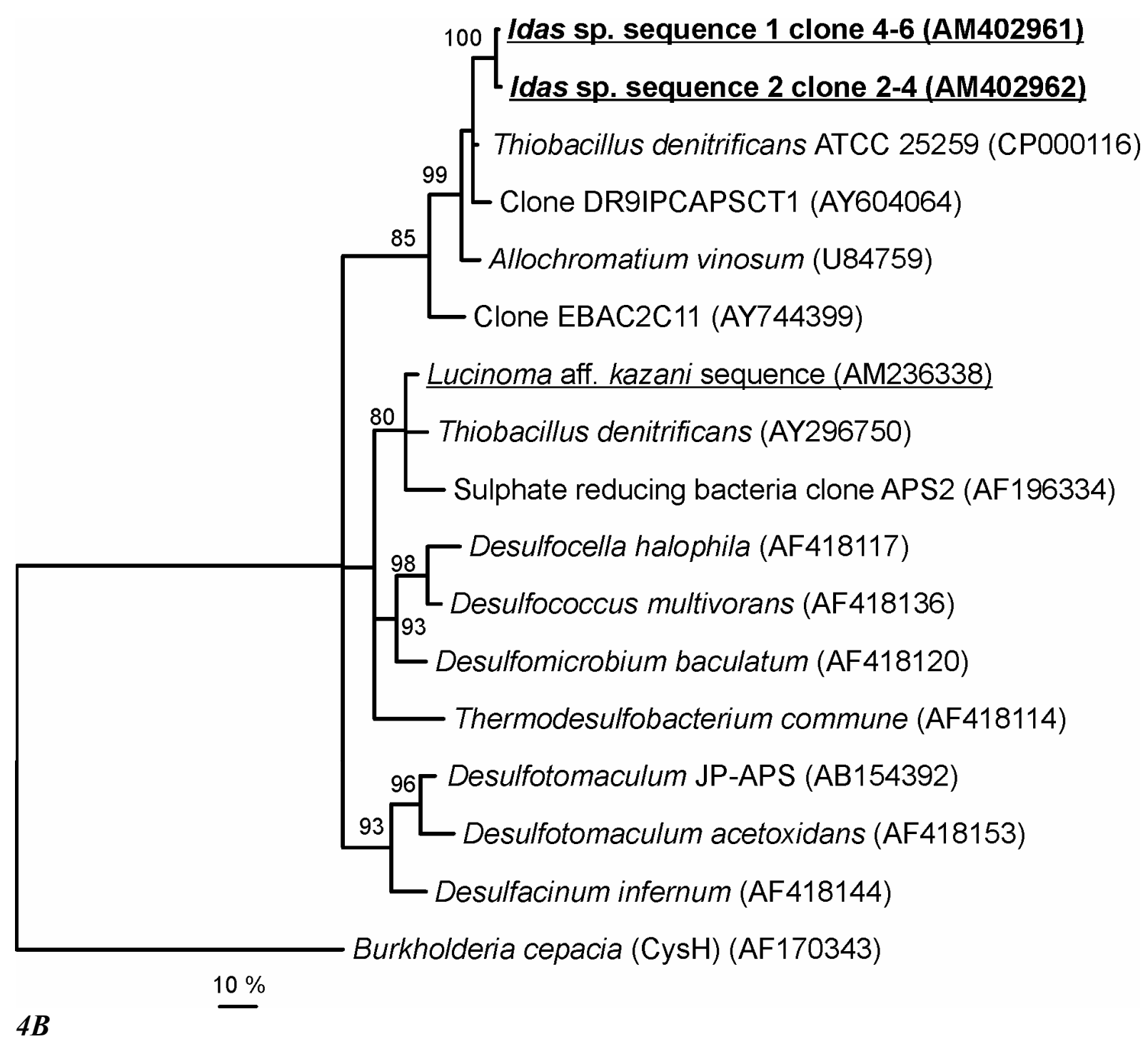




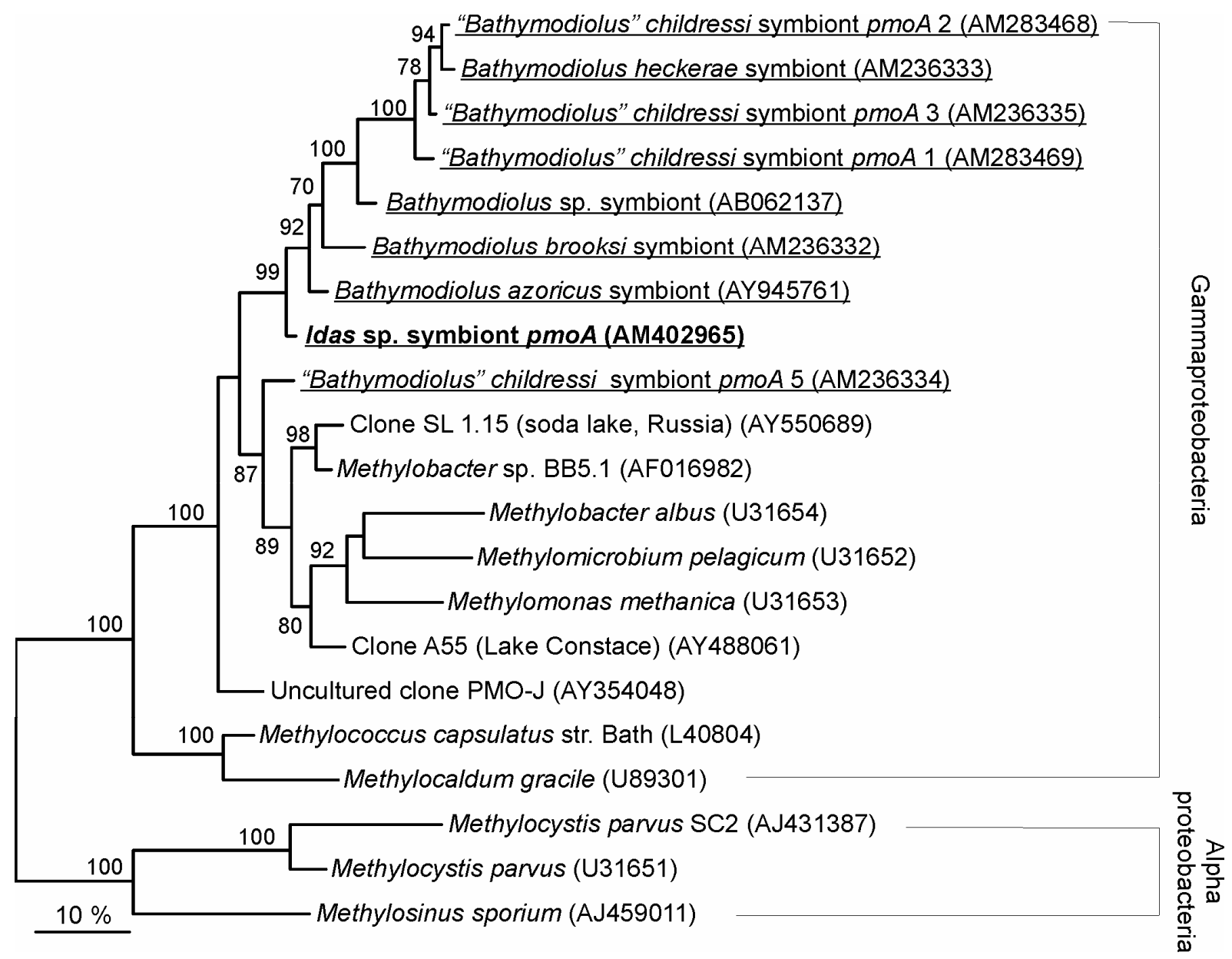

$4 C$ 